International Journal of Curriculum and Instructional Studies

11(2), 2021, 237-260

EPÖDER

www.ijocis.com

\title{
Curriculum Theory: A Review Study
}

\author{
Gülşah Coşkun Yaşar, Instructor, gcoskunybu@edu.tr, (D) 0000-0002-6778-0713 \\ Berna Aslan, Assoc. Prof. Dr., baslan@ankara.edu.tr, (D) 0000-0002-0967-3274
}

\author{
Keywords \\ Curriculum theory \\ Curriculum beliefs \\ Curriculum ideologies \\ Curriculum orientations
}

\section{Article Info:}

Received : :17-09-2021

Accepted : 21-12-2021

Published : 28-12-2021

\begin{abstract}
The aim of this literature review study was to examine the historical development of the concept of curriculum theory, its reflections on curriculum development studies, and teaching-learning processes and also to attract the attention of the researchers to the area of curriculum theory which was seen to be left aside for years. The research was designed by reviewing the literature, and different theoretical perspectives on curriculum development studies in the USA which historically dominated the field since the early 1900's and Turkey were examined. In the first phase, the explanation of the concepts of curriculum, theory, curriculum theory, the chaotic structure, and discussions in the literature regarding the terminology of these concepts were given. It was concluded that in the literature the concept of curriculum theory has been used synonymously with the concepts of curriculum beliefs, educational value orientations, curriculum ideologies, and curriculum orientations. In addition, the classification of curriculum theories, curriculum development studies in which the reflections of curriculum theories could be seen, and the studies conducted in Turkey and abroad on this subject were included in the study. Taking the limited number of studies on curriculum theories and their lack of variety into account, future studies on curriculum theory are considered to feed the intellectual background of the field and attract the attention of the researches to theories of curriculum, which will fill the gap in the literature.
\end{abstract}

To cite this article: Yaşar, C. G., \& Aslan, B. (2021). Curriculum theory: A review study. International Journal of Curriculum and Instructional Studies, 11(2), 237-260. DOI: 10.31704/ijocis.2021.012

\section{Introduction}

The curriculum is the constitution of education that directs an education system and defines the individuals to be raised in the society. Curricular decisions offer important clues that will affect the entire teaching-learning process. During the curriculum-developing process, what knowledge is of most worth, what should we teach? (Spencer, 1884); why should we prefer to teach one thing over another?, who can reach what knowledge?, in order to obtain a whole from the different parts of the curriculum, how should these parts be interrelated? (Kliebard, 1977) are important questions to answer. In addition, what should be taught and to whom, under what conditions, for what purpose should it be taught, and what processes should be exploited when taking curriculum decisions? are 
also the other important questions to be asked (Null, 2016). There is a need for deep inquiries and questions asked to curriculum are of great importance. Such questions include: Is the nature of the knowledge in the curriculum sourced from didactic teachings, individual interpretations, abilities and competencies, or cultural and moral perspectives? Is learning handled from the perspective of the person receiving the knowledge or the person transmitting it? Are the students passive or active subjects of the teaching-learning environment? Are the teachers in the role of the transmitter or the supervisor of the teaching and learning environment? What is the goal of evaluating students? Is it to determine their future success in the discipline, to show that a student has certain skills, to determine students' capacities to ease their growth, or to evaluate students' development in their abilities? (Schiro, 2012) The questions like these can find their answers only after intense thinking processes (Null, 2016).

These deep inquiries show which intellectual planning, infrastructure, ideological and philosophical perspectives are at the heart of the curriculum. This process is shaped around the answers obtained during the curriculum making process. In this sense, curriculum theory deals with these ideological views and beliefs which form the infrastructure of curriculum within a systematic thinking. In order to touch on points, such as: What is curriculum theory, what are the different curriculum theories, what are the principles of these theories?, how curriculum theories were handled and are being handled in the world and in our country, primarily, it is necessary to explain what the concept of curriculum theory is.

After elaborating on what curriculum theory is and its classifications by different curricular theorists, how curriculum theory reflected on Turkish and American education systems was touched on. The field of curriculum emerged in the United States in the early 1900s, and the American scholar Bobbit's (1918) works were seen as the birth of the field. In addition, the start of the curriculum theory field was also regarded to have roots in the conference held in Chicago in 1947 (Klein, 1992; Kliebard, 1977; Tyler, 1977). As seen, there is a huge impact of American scholars and studies on the field of curriculum and the development of the concept of curriculum theory. Because of these reasons, in this study the historical perspective of the curriculum theory was examined within the American and Turkish contexts. In addition, in order to see and analyze how curriculum theory was addressed in the studies from a broader perspective, both the national and international research on the curriculum theory was examined.

\section{Method}

This study is in the form of a literature review, which was prepared by examining the studies on the concept of curriculum theory in the literature. As a result of the examinations in the literature, both national and international articles and theses were taken into consideration. To review the studies on curriculum theory, key words, such as "curriculum theory", "curriculum orientation", "curriculum ideologies" were used, and a literature review was conducted based on articles and theses published in ScienceDirect, Jstor, Google Scholar, Proquest and the National Thesis Center of the Council of Higher Education. When the studies were examined; the year and the country of publication, the title, the purpose, the sample of the studies, data collection instruments, the data collection processes, findings and the implications of the studies were taken into account.

\section{Conceptual Framework}

\section{What is Curriculum?}

Before elaborating on the concept of curriculum theory, first of all, the word curriculum and then the concept of theory should be explained (Beauchamp, 1982). The concept of "curriculum" has been defined in many different ways like the word "education" (Demirel, 2005; Dewey, 1986; Durkheim, 1956; Ertürk, 2016; Sönmez, 2015; Tyler, 2014). For this reason, the terminology of the word 
curriculum has a quite chaotic structure (Beauchamp, 1972; Ellis, 2015; Goodlad,1979; Jackson, 1992, Walker, 1982).

Mızıkacı (2017) stated that curriculum terminology should be evaluated at two extremes in terms of curriculum and currere concepts. Curriculum corresponds to listing and ordering items one by one in Arabic, while the word currere has a post-positivist meaning that expresses action rather than passivity. Currere has evolved from the meaning of running to the metaphor of the path followed (Ellis, 2015). The curerre meaning of the curriculum has a rich background, and it has been affecting the field of curriculum (Bintz \& Dillard, 2007).

Considering the different definitions of the curriculum before and after positivism, different terminological structures can be found for the word curriculum. Dewey (1902) accepted the standardized curriculum definitions but stated that the curriculum should start from the child. He also stated that the teacher should establish a link between the child and the curriculum. Therefore, Dewey defined the curriculum as a composition of planned experiences. In 1918, Bobbit made a more comprehensive definition and stated that in addition to planned experiences, unplanned experiences should also be included. Bobbit (1918), emphasizing adult life skills in the definition of the curriculum, defined the curriculum as a structure that includes a series of actions and skills that children and young people need to acquire in order to do the jobs making up the adult life well. Kliebard also expanded Bobbit's definition by identifying unplanned experiences as hidden and null curriculum (Kridel, 2010). While Taba (1932) defined the curriculum as the whole of experiences at school, Tyler (1975) described the curriculum as the whole of student experiences at school, both planned and unplanned.

One of the narrow-scoped definitions of the curriculum defined by very different perspectives and viewpoints belongs to Phenix (1962). He described curriculum as content or subject area learned at the school. A definition in the same direction belongs to Squires (1990), and he defined the curriculum as "what is taught". Dealing with the curriculum as opportunities, Saylor and Alexander (1974) defined the curriculum as a structure encompassing all learning opportunities provided by the school. In the same direction, according to Oliva (1988) curriculum is the series of experiences that the student encounters at school, the discipline, subject, and materials taught at schools, that is, it is everything planned by the school. Bilbao, Luncido, Lringan, \& Javier (2008) also defined the curriculum not only as learning experiences at school, but as all learning experiences in the society. Ornstein \& Hunkins (2016) considering the curriculum as a system and making a definition close to Oliva's explained the curriculum as a structure in which objectives, subject area, learning experiences, and evaluation techniques are planned.

When the definitions of the curriculum in Turkish literature were analyzed, it can be found that Varış (1996, p.14) defined the curriculum as all the activities of an educational institution provided for children, youth, and adults towards the realization of objectives of the National Education and the institution. It can be also concluded that Ertürk (2016) used the Turkish word "yetişek" for curriculum and described it as a systematic mechanism for teaching-learning processes which aim at educating students in a certain period of time. It can also be stated that according to Demirel (2006), the curriculum is a written document or an action plan in which strategies are set to achieve desired goals and behaviors.

When looking at the various definitions of the curriculum in the literature, it is possible to see that the concept of curriculum has been handled as what is taught in schools, a subject area, content, a set of materials, everything planned by the school, and a set of experiences gained by students in a school (Marzooghi, 2016). Although there are curriculum definitions from different perspectives in the literature, it can be easily seen that there has been a constant effort to make a better and single definition. When the definitions are examined, it is clear that some of the definitions focus on the experiences of the students, some of them take the competencies required for preparation for adult life to forefront; while some definitions consider the curriculum as a system, some deal with the word 
curriculum as a content. Bintz \& Dillard (2007) stated that the curriculum was defined as a lived experience, as a tool to prepare students for life, as a system, as a plan for a specific subject area, as a content, as an activity or opportunity, as a tool helping teachers to make decisions on teaching, and as a belief system by various researchers in the literature. These definitions different from each other are undoubtedly due to the fact that both education and curriculum have a changeable structure in line with the current needs of the society. The various definitions of the curriculum in the literature (Bellack \& Kliebard, 1977; Kliebard, 1989; Oliva, 1977; Portelli, 1987; Rasco, 2016; Schubert, 1986) were interpreted positively as the different meanings of the curriculum concept is considered to feed the area of curriculum and curriculum studies, and there is also an opinion that these different definitions indicate the problems waiting to be solved in the curriculum area, so this situation is regarded to create awareness of these problems (Goodlad, 1979; Jackson, 1992; Posner, 1995; Tanner \& Tanner, 1975). For this reason, it has been stated that the effort to reach a uniform and the most accurate definition is in vain (Goodlad, 1979; Rasco, 2016; Varış, 1996).

\section{What Is Theory?}

In an effort to answer the question "What is curriculum theory?" as Beauchamp (1982) also stated it was necessary to clarify in what sense and how the word "theory" was used in the concept of curriculum theory. In the dictionary of Turkish Language Society, the word theory has been defined in different ways. According to the dictionary, theory has been described as an abstract information handled practice-free; collection of thoughts or opinions on a particular subject, and a set of rules and laws that explain many systematically organized events which are the basis of science. In the Oxford dictionary, theory has been defined as a set of formal ideas intended to explain why something happens or exists, a set of principles which belongs to a particular topic, and an idea or thought that is believed to be true but not proven. Beauchamp (1982), on the other hand, defined theory as an integrated structure of assumptions and general assertations from which a set of testable hypotheses on a particular topic could be logically deduced.

When the different definitions of theory were analyzed, it was seen that the theory has a wide range of terminology just like the concept of curriculum. Theory has been conceptualized, applied and discussed in many different ways (Beauchamp, 1972; Nestel \& Bearman, 2015). As Beauchamp (1972) states there may be differences in the definitions of the theory, but the word theory gains a meaning specific to the field in which it is theorized. For this reason, the word theory within the concept of curriculum theory has evolved into a meaning specific to the field of curriculum.

\section{Curriculum Theory}

When looking at the history of the concept of curriculum theory, it is necessary to draw attention to the conference (Klein, 1992; Kliebard, 1977; Tyler, 1977) held at the University of Chicago in 1947. After the conference Herrick and Tyler wrote the article "Toward Improved Curriculum Theory" in 1950 (Klein, 1992). With this study, the concept of curriculum theory started to attract more attention. In the article and the conference, it was emphasized that curriculum development would be incomplete without curriculum theories, and the importance of curriculum theories was dwelt on (Klein, 1992; Kliebard, 1977).

Macdonald (1971) stated that curriculum theory is one of the least understood concepts in the curriculum area, but it basically means examining what kind of a learning environment to have. Beauchamp (1982) defined curriculum theory as a set of propositions which add meaning to a school's curriculum acting in relation as a whole. McCutcheon (1982) also considered curriculum theory as a set of analysis, interpretation and understanding of curriculum phenomenon. Curriculum theory is defined in the Encyclopedia of Curriculum Studies as an interdisciplinary curriculum study that deals with the curriculum in historical, sexist, political, racial, international, post-modern, autobiographical, and religious dimensions (Kridel, 2010). For this reason, curriculum theory, which is closely related to 
our views on what is true and important about ourselves and our world, actually extends to our individual, social and cultural depths (Walker \& Soltis, 2004).

When Schiro (2020)'s book was examined, it was seen that he also used the concepts of ideology, philosophy, belief, vision, and perspective while referring to the terminology of curriculum theory. He used the concept of curriculum ideology instead of the concept of curriculum theory and explained the word ideology that he used intensely as "a community of ideas, a comprehensive view, a way of looking at things, or a world view that represents people or groups who believe that the world should be organized and function" (Schiro, 2020, p.10).

When viewed from this respect, the conceptual structure of the word "curriculum theory" has a chaotic structure like the sub-words composing it. As Walker (1982, p. 62) states curriculum theory is many things to many people. In the literature, curriculum theory has been expressed in the same way with concepts, such as curriculum beliefs, educational value orientations, curriculum ideologies, curriculum orientations, but no information has been found in the literature as to the fact that these expressions have different meanings from each other (Cheung \& Wong, 2002; Schiro, 2012; Yılmaz, 2021).

Schiro (2020) stated that curriculum ideology was related to the effort made when people deal with the curriculum and question the problems of it. Cheung \& Wong (2002) who used the expression curriculum orientations for the concept of curriculum theory, on the other hand, referred to this concept as a collective set of beliefs about elements, such as curriculum objectives, content, instructional strategies, and evaluation.

\section{Classification of the curriculum theories}

The views of curriculum theorists and the reflections of these different curriculum theories on teaching-learning processes differ from each other (Huebner, 1975; Macdonald, 1971; Morris \& Hamm, 1976). Curriculum theories handled in different ways and named differently have been in an effort to create a system of thought about the curriculum. Although put in different categories by different theorists, it will be seen that the different curriculum theories express the same ideas in terms of meaning and content when examined in detail (Huenecke, 1982).

The first classification for curriculum theories that will be examined in this study is Eisner and Vallance's (1974). Eisner \& Vallance (1974) identified academic rationalism, technology, cognitive processes, self-actualization, and social reconstruction-relevance theories. Academic rationalism curriculum theory is the most traditional one and emphasizes students' commitment to Western cultural elements. It is important for the students to have access to great ideas and objects. Technology curriculum theory, on the other hand, focuses on predetermined goals. For this theory, it is important to ensure systematic planning and effective teaching. Cognitive processes theory, on the other hand, argues that students' mental processes should be improved, and according to the proponents of this theory, the focus should be on the "how" rather than "what" of the curriculum. The other two curriculum theories in Eisner \& Vallance's (1974) classification are "the self-actualization curriculum theory", which sees education as a process that ensures individual freedom, and "the social reconstruction-relevance theory", which sees social needs more important than the individual's needs.

In McNeil's (1977) curriculum theory classification, there are academic, technological, humanist, and social reconstructionist curriculum theories. According to humanist curriculum theory, it is important to provide students with fundamentally useful experiences. Social reconstructors, on the other hand, focuses on improving social values and developing critical thinking processes with the help of the curriculum. Theorists advocating the technological curriculum theory, on the other hand, consider predetermined and measurable goals important. According to advocators of the academic curriculum theory, students should learn the details of a discipline. 
Posner's (1995) curriculum theories can be analyzed in five groups as traditional, experiential, disciplines (structure of the disciplines), behavioral and constructivist curriculum theories. Traditional curriculum theory emphasizes the necessity of transferring cultural heritage. Experiential theory, on the other hand, focuses on all of the student's intramural and extramural experiences. According to the disciplines curriculum theory, students should learn the fundamentals of the discipline. Behaviorist curriculum theory advocates that what students can do should be decided at measurable levels, and the performance of them should be measured periodically. In constructivist curriculum theory, the curriculum starts with what students already know. Students build their own knowledge themselves, and this knowledge is used in meaningful activities.

According to the intellectual traditionalists, the first curriculum theory of Schubert (1996), primary sources and textbooks must be reached in order to generate ideas. Secondly, social behaviorist curriculum theory thinks that the behaviors of students and teachers should be observed, and thus the answer to how the student can learn better can be found. Experientialists, on the other hand, focus on student experiences, and finally, critical reconstructionists emphasize the importance of students' taking an active role against racial, class, and cultural differences in schools and reorganizing society.

Ornstein \& Hunkins (1998) grouped curriculum theories as "technical and scientific" and "nontechnical/nonscientific". Technical and scientific curriculum theories are behaviorist, managerial, system, and academic curriculum theories. In the category of non-technical and non-scientific curriculum theories, there are humanist and reconceptualist/postmodern curriculum theories.

Kliebard (2004) stated that "the humanist curriculum theory" focused on the idea of providing liberal education for all. It focuses on teaching academic subjects, the power of reason, and adherence to traditions. According to Kliebard's (2004) "child study curriculum theory", the curriculum should be arranged in accordance with the child's natural development by taking the child's interests and needs into account. Thirdly, "social efficiency curriculum theory" emphasizes that the curriculum should equip students with future competencies in society and prepare them for their future roles. Finally, "the social meliorist theory" gives importance to social change and social justice concepts. It emphasizes addressing the problems in the society.

The three curriculum theories identified by Ellis (2004) are "knowledge-centered/academic", "learner-centered", and "society-centered" curriculum theories. According to "the knowledgecentered curriculum theory", students should receive liberal education, and an academic education should be prioritized. "The learner-centered curriculum theory" focuses on the interests and needs of students. "Society-centered curriculum theory", on the other hand, thinks that problems of the community should be discovered and solved through curriculum.

According to "the scholar academic curriculum theory of Schiro" (2012), children should learn the accumulated knowledge of culture, and an effort should be made to understand an academic discipline in depth. "Social efficiency theory", on the other hand, emphasizes the importance of preparing students for their future roles in order to grow up properly as adults of the future. "The learnercentered curriculum theory" advocates that the natural development of students should be ensured by considering their intellectual, social, emotional, and physical features through the curriculum. Finally, "social reconstruction curriculum theory" thinks that awareness should be created about social problems and injustices arising from racial, sexual, social, and economic inequalities. Through the curriculum, a fairer society structure should be provided.

Null (2016) classified curriculum theories as liberal, systematic, existentialist, radical, pragmatic, and deliberative theories. According to "the liberal curriculum theory", it is considered important to raise intellectually and morally complete individuals, and the development of the mind should be ensured through curriculum. "Systematic curriculum theory", on the other hand, focuses on accountability in student performance, standardized tests, and the roles that students should fulfill as adults in the future. "The existentialist curriculum theory" particularly attaches importance to 
students' gaining emancipatory experiences and setting out on an inner journey of liberation. "Radical curriculum theory" focuses on social change and reconstruction. "The pragmatic curriculum theory", on the other hand, attaches importance to the students' gaining meaningful experiences through the curriculum. Finally, "deliberative curriculum theory", concerned more with curriculum-making process, focuses on finding practical solutions to the problems of the curriculum through deliberation.

Considering the different classifications of the curriculum theories, it can be seen that the views, aims, and principles advocated by different curriculum theories converge on the same points despite being named differently from each other. For example, according to technological, social efficiency, behavioral, social behaviorist, managerial, system, and systematic curriculum theories, objectives of the curriculum should be determined as observable skills, the curriculum shaping people's behavior should be designed, performance standards should be determined, and the skills that will prepare students for future life should be provided. Although named differently from each other, selfactualization, humanist, experiential, constructivist, learner-centered, pragmatic, and existential curriculum theories all prioritize organizing curriculum around the needs and interests of individuals, acquiring first-hand experience, focusing on the nature of the child, and the autonomy of the students. The principles of social reconstruction, critical reconstruction, social meliorism, and society-centered, and radical curriculum theories have the idea that education has the necessary power to restructure the society, it is possible to raise individuals who can understand the problems of the society, offer solutions to these problems, and approach to community problems critically. Academic rationalism, academic disciplines, intellectual traditionalists, scholar academic, humanist, knowledge-centered, and liberal curriculum theories see the main purpose of the school as acculturation of students in the world of knowledge, consider the curriculum as a reflection of the disciplines, and think that the development of the mind and teaching the disciplines in detail are important (Eisner \& Vallance, 1974; Ellis, 2004; Kliebard, 2004; Mcneil, 1977; Null, 2016 Ornstein \& Hunkins, 1998; Posner, 1995; Schiro, 2012; Schubert, 1996).

Another important point in the classification of curriculum theories is about the deliberative curriculum theory included in Null's (2016) classification. This curriculum theory has taken its place in the curriculum theory classification as a theory which has principles about the process of curriculum making not about the teaching-learning process. In contrast to the curriculum theories named differently, but corresponding to similar principles, Kliebard's (2004) humanist curriculum theory has the same principles like liberal education-oriented curriculum theories although its name connotates learner-centered theories. In Table 1, the different and same points of the curriculum theories can be examined in more detail, and the theories discussed in this study can be seen as a whole picture. 


\begin{tabular}{|c|c|c|c|c|c|c|c|c|}
\hline $\begin{array}{c}\text { Eisner \& } \\
\text { Vallance (1974) }\end{array}$ & Mcneil (1977) & $\begin{array}{l}\text { Posner } \\
(1995)\end{array}$ & Schubert (1996) & $\begin{array}{c}\text { Ornstein \& } \\
\text { Hunkins (1998) }\end{array}$ & $\begin{array}{c}\text { Kliebard } \\
(2004)\end{array}$ & Ellis (2004) & Schiro (2012) & Null (2016) \\
\hline $\begin{array}{l}\text { Technology } \\
\text { \& Cognitive } \\
\text { Processes }\end{array}$ & Technological & Behavioral & Social Behaviorist & $\begin{array}{c}\text { Behavioral \& } \\
\text { Managerial \& } \\
\text { Systems }\end{array}$ & $\begin{array}{c}\text { Social } \\
\text { Efficiency }\end{array}$ & & Social Efficiency & Systematic \\
\hline $\begin{array}{c}\text { Self- } \\
\text { Actualization }\end{array}$ & Humanist & $\begin{array}{c}\text { Experiential } \\
\& \\
\text { Constructivis } \\
\mathrm{t}\end{array}$ & Experientialists & Humanist & Child Study & $\begin{array}{l}\text { Learner- } \\
\text { Centered }\end{array}$ & $\begin{array}{l}\text { Learner } \\
\text { Centered }\end{array}$ & $\begin{array}{c}\text { Existentialist \& } \\
\text { Pragmatic }\end{array}$ \\
\hline $\begin{array}{c}\text { Social } \\
\text { Reconstruction } \\
\text { Relevance }\end{array}$ & $\begin{array}{c}\text { Social } \\
\text { Reconstruction }\end{array}$ & & $\begin{array}{c}\text { Critical Reconstruction- } \\
\text { alists }\end{array}$ & $\begin{array}{l}\text { Reconceptualist } \\
\text { /Postmodern }\end{array}$ & $\begin{array}{c}\text { Social } \\
\text { Meliorist }\end{array}$ & $\begin{array}{l}\text { Society- } \\
\text { Centered }\end{array}$ & $\begin{array}{c}\text { Social } \\
\text { Reconstruction }\end{array}$ & Radical \\
\hline $\begin{array}{c}\text { Academic } \\
\text { Rationalism }\end{array}$ & Academic & $\begin{array}{c}\text { Structure of } \\
\text { the } \\
\text { disciplines/D } \\
\text { isciplines \& } \\
\text { Traditional }\end{array}$ & Intellectual Traditionalists & Academic & Humanist & $\begin{array}{c}\text { Knowledge- } \\
\text { Centered \& } \\
\text { Academic }\end{array}$ & $\begin{array}{c}\text { Scholar } \\
\text { Academic }\end{array}$ & Liberal \\
\hline & & & & & & & & Deliberative \\
\hline
\end{tabular}




\section{Reflection of the Curriculum Theories on American and Turkish Education Systems}

In the early 1900's, the curriculum field was launched in the USA with developments in scientific research methods, psychology, the child studies movement, industrial efficiency, and the progressive movement influencing the education between 1918-1949 (Ornstein \& Hunkins, 2016). In this period, curriculum started to be seen as a planning instead of just ordering the courses and defining the time allocated to the them. Taylor, examining the working conditions in the factory was influenced by scientific management theory and stated that efficiency and productivity would increase by paying the workers taking their own output and productivity into account. Along with Taylor's views, the idea of efficiency and production influenced by business and industry also had an impact on the views of Bobbit and Charters.

The most fundamental consequence of this situation in terms of the curriculum field was that Bobbitt combined Taylor's approach with curriculum development. Bobbit wrote the book "The Curriculum" with the idea of activity analysis (Posner, 2004; Null, 2016). In the USA, Franklin Bobbitt (1918) emphasized the need to set the goals of the curriculum clearly, as he thought the age of science demanded precision and clarity (Kelly, 2004). He described a range of tasks that children and young people must do and experience in order to develop skills that would be required in their future lives (Ornstein \& Hunkins, 2016). Charters, like Bobbitt, adopted activity analysis steps, but he updated that practice to teacher training. He examined teacher education curriculum contents and teacher activities between 1925 and 1928. At the end of that examination, a mastery list was created in which 1001 teacher traits were listed (Null, 2016).

Considering the ideas of Bobbit, Charters, and Taylor, an approach attracts attention that instructional efficiency is at the forefront, predetermined learning goals are taken into account, goals and student-teacher behaviors are clearly listed, and the curriculum content is sequentially arranged. It is possible to see the reflections of technological, systematic, social efficiency, and social behaviorism curriculum theories in the views and practices of those curriculum researchers.

During this period, John Dewey's work at the University of Chicago Laboratory School from 1894 to 1904 drew the attention into his ideas on education for democracy, community participation in learning, student empowerment, and applied problem solving. Dewey persistently argued that education was based on the continuous restructuring of experiences that emerge through student interest and active inquiry (Ellis, 2004).

Kilpatrick (1918), who had similar ideas with Dewey, introduced "the Project Method" to the curriculum field. The curriculum should be organized around social activities and group work in classroom and school. He argued that the learner should take part in curriculum planning. At this point, Kilpatrick differs from Dewey, who puts more emphasis on the teacher. While reading, writing, arithmetic skills, and learning academic disciplines are important in traditional education, Kilpatrick argues that the purpose of education is to complete the child's development in social context (Ornstein \& Hunkins, 2016).

Bobbit and Charters were at the University of Chicago, while Tyler was a graduate student at the same university, and he was Charters' assistant. Thus, Tyler was also heavily influenced by the behaviorist ideas of Bobbit and Charters. Tyler's four main curriculum components (objectives, learning experiences, organization of methods, and evaluation) were influenced by the ideas of Bobbitt and especially Charters (Bellack, 1969; Ornstein \& Hunkins, 2016). Tyler's approach is actually a combination of behaviorism (focusing on goals) and progressivism (considering student needs) (Null, 2016; Ornstein \& Hunkins, 2016;).

The Eight-Year Study, marking curriculum field in the USA between 1932-1940, was carried out as a comparison of progressive schools and their curriculum from traditional schools and their curriculum. According to the results of the study, progressive methods were found to be at least as successful as 
traditional methods (Ellis, 2004; Ornstein \& Hunkins, 2016). The Eight-Year Study paved the way for Tyler's (1949) book "The Basic Principles of Curriculum and Instruction" (Ornstein \& Hunkins, 2016). As it can be understood, the period between 1918-1930 was a period that can be thought as the culmination of the effect of progressive, learner-centered, and humanist curriculum theories (Ellis, 2004). According to the Hadow Report published in 1931, it was stated that the primary school curriculum should not be considered as knowledge, content, and product to be acquired, in contrast, it should be considered in terms of activity and experience emphasizing the process (Kelly, 2004).

After the rise of progressive ideas in curriculum, Counts, at the conference held by Progressive Education Association in 1932, criticized the progressive approach quite harshly in his speech titled "Dare the school build a new social order?" (Counts, 1978; Null, 2016). He stated that the progressive education detaches the child from the real life, and it doesn't contribute much to the sociality of the child (Counts, 2013). With those views, Counts stated that the progressive approach didn't serve any social purpose, and child-centered education supported classism rather than fighting against it, which caused the conference to be canceled (Null, 2016). Counts argued that schools could be used either to eliminate social inequalities or to reform culture and society. When viewed from this aspect, Count's ideas have roots in critical reconstruction, social meliorists, society-centered theory, and radical curriculum theories.

By the middle of the $20^{\text {th }}$ century, there was an atmosphere of panic in American education when Russia launched its satellite Sputnik into space during the cold war between America and Russia in 1957 (Kridel, 2010; Null, 2016). With this event, the country made an effort to develop a curriculum that focused on science and technology (Kelly, 2004). Thus, this event led to a decrease in the influence of the humanist, experiential, learner-centered curriculum theory views in the United States (Tanner \& Tanner, 1975).

Since the mid-1960s, there had been a period in which the theoretical legitimacy of the field had been questioned (Bümen \& Aktan, 2014). In those periods, the influence of economists and politicians on the curriculum grew significantly, and an education approach that focused on student achievement and test scores instead of critical and independent thinking began to dominate the field (Ornstein \& Hunkins, 2016). For those reasons, the 1970s was a period when the field of curriculum went through a paradigm shift, and the field was reconceptualized (Pinar, Reynolds, Slattery, \& Taubman, 2004). Schwab stated in 1969 the curriculum field was moribund, and it could not continue with the current methods and principles. He also said that new and more effective principles and methods should be sought by giving more weight to practice (Bümen \& Aktan, 2014; Null, 2016; Pinar, 2004 et al.; Schwab, 1969). The reconceptualization movement, whose most important advocator was William F. Pinar, emerged in the USA in the 1970s and opposed the traditional curriculum development approach (Bümen \& Aktan, 2014).

When all these developments are examined from the perspective of curriculum theories, the understanding of curriculum development made with predetermined goals and prescriptive methods and based on social efficiency, social behaviorist, and systematic curriculum theories, was born in 1918 and died in 1969. An effort to understand curriculum with the reconceptualization movement started in 1970 (Bümen \& Aktan, 2014; Pinar et al., 2004).

The reconceptualization movement, shaped by the thoughts of Michael Apple in the 1970s, argues that the curriculum should be understood as a political, racial, phenomenological, postmodern, biographical, aesthetical, religious, organizational, and universal text (Bümen \& Aktan, 2014). Apple has written actively in the curriculum field since the early 1970s and has criticized American education and its curriculum heavily. He stated that American schools had inequal and classist behaviors towards minority groups, and education in the country wasn't organized according to the needs of those groups. For this reason, the need for radical curriculum theories emerged in educational institutions and curriculum field in the United States (Null, 2016). 
After mentioning "the social reconstruction curriculum theory approach" advocated by Apple, the curriculum approach of the Brazilian educator Paulo Freire with radical and social reconstruction view of the curriculum like Apple and how and in what way his ideas affected the curriculum area should be addressed. In the "Pedagogy of the Oppressed" that he wrote in the 1970s, he discussed terms like dialogue, banking concept, and consciousness. He stated that the banking model controls students' thinking and actions and limits their creativity. Instead of the corrupt banking model in education, educators should implement teachings based on dialogues (Null, 2016; Ornstein \& Hunkins, 2016). Freire's critique of that dominant education model led to an education aware of social problems and a more democratic approach (Ornstein \& Hunkins, 2016).

In the 1980s, it can be said that the "Back to Basics Movement" started in curriculum field in the United States (Ornstein \& Hunkins, 2016). As its name signifies, along with the view that retracted the curriculum understanding to the systematic, social efficiency, and social behaviorist curriculum theories the reflections of "the Back to Basics Movement" were as follows. In 1983, NCEE published a report called "A Nation at Risk". It was stated that the country was under economic threat, and the current education system, and curriculum were responsible for that situation. The poor test scores compared to other countries made it necessary for the curriculum to wend its way towards perfectionism and more challenging academic courses (Posner, 2004). The next "Back to Basics Movement" was the establishment of clearly defined National Goals for Education created in 1990 and reorganized in 1994 and 1998 in the hope of putting the country among internationally competitive ones (Ornstein \& Hunkins, 2016; Porter, 1990).

The "No Child Left Behind" (NCLB) movement emerged in 2001 aimed to increase the student success and close the proficiency differences among students via tests done yearly (Darling-Hammond, Noguera, Cobb, \& Meier, 2007). According to this approach, curriculum should be written precisely just like writing a prescription, and there should be no ambiguities in it. This movement argued that when the curriculum was kept under control, same effect on students' academic success could be ensured (Null, 2016). The aim of providing equal education rights for the disadvantaged students with the help of standardized tests, evaluation, and accountability methods were expressed as the aims of the movement (Hursh, 2004). In relation to all that information, the ever-increasing performance evaluations and accountability requirements in education seemed to be made for the benefit of minority groups, but in fact, they took the curriculum understanding back to systematic approaches.

The intellectual, periodic and social background elements determining the structure of the curriculum studies affect the decisions about the curriculum (Mızıkacı, 2019). In this regard, understanding of the curriculum in Turkey should not be considered as disconnected from the developments in the other countries. When looked at the historical framework of curriculum development, with the proclamation of the Republic, the question "What knowledge is of most worth?" was answered quite differently within the effect of positivism and secularism (Aktan, 2013). A nation that had just come out of the war in the 1920s was trying to rise again, and education and curriculum studies were of great importance.

Efforts to make curriculum in Turkey started after the proclamation of the Republic, but its transformation into a systematic structure corresponds to the 1950s (Akınoğlu, 2005; Demirel, 1992; Orakçı, Durnalı, \& Özkan, 2018). With the proclamation of the Republic, the curriculum began to be considered as a more political text. Since curriculum studies done in that period were mostly aimed at reconstructing the society, it can be said that those curricula were a kind of social engineering projects (Bümen \& Aktan, 2014). In this context, it can be said that because of aforementioned feature of the curricula in the first years of the Republic, they were mostly made with the understanding of radical, social reconstruction curriculum theories.

The 1924 curriculum was the curriculum prepared as a project considering the needs and conditions of a newly established country and remained in practice for two years (Gözütok, 2013b). John Dewey's 
visit to Turkey in 1924 and his report on Turkey's education were the government's important projects for the newly recovering country's education and curriculum. The reflections of his recommendations could be easily seen in the primary school curriculum and teacher training. In general, the ideas of teacher-centered instruction were more visible in the 1924 curriculum (Aktan, 2003).

The 1926 curriculum prepared for the first time in accordance with the broad fields design, is accepted as a progressive curriculum (Aslan, 2000; Beyaztaş). The ideas of Dewey were more visible in 1926 curriculum as the main target of the primary school curriculum was mentioned to bring up good people by connecting the students to their environment. In addition, the relation between schools and the community was very strong in the 1926 curriculum because it was thought that the schools were seen as a form of reconstruction (Aktan, 2013). Likewise, in the 1936 curriculum; the points, such as putting the student and his/her environment at the center, acting on the interests of the students, gaining the knowledge and skills appropriate to their needs, and the cooperation taking an important place in the curriculum (Beyaztaş, et al., 2013; Türe, 2013) can be accepted as some clues to learnercentered and progressive curriculum theories. Aktan (2013) also stated that 1936 curriculum focused on the nationalist ideology, and he also mentioned that the pragmatism idea seen in the curriculum wasn't a democratic but a more ideological one.

With "the Village Primary School Curriculum Project", which was put into practice in the 1939-1940 academic year, practical lessons about village life were included in the curriculum of village schools, and steps were taken to make the contents of some lessons suitable for village life. The Village Institutes emerged with the idea of training teachers who would implement the new village school curriculum (Gözütok, 2013b).

During the post-war period, the 1936 curriculum in practice during the Word War II couldn't answer to the needs of that period as it was based on the single-party ideology (Aktan, 2013). Considering the 1948 curriculum, the transition to multi-party system coinciding with those years cannot be ignored. The 1948 curriculum gave importance to democratic processes (MEB, 1948). Aktan (2013) also commented that discourse of democracy substituted for the ideological focus in the 1936 curriculum. In addition, he stated that in the 1948 curriculum the themes like social, individual, human affairs, and economic life were seen important, which weren't seen in the 1924, 1926 and 1936 curricula. The 1948 curriculum included alternative measurement methods, and gave importance to practical knowledge and skills. For such reasons, it can be said that the 1948 curriculum also had reflections of the progressive and pragmatist perspectives (Aktan, 2013; Beyaztaş, et al., 2013). However, it could be also said that the 1948 curriculum was based on knowledge teaching as the number of subjects and units for each course were increased, and there was a loaded content (Gözütok, 2013b).

The World War II could be regarded as a turning point for Turkish curriculum studies. The curriculum concepts from Continental Europe especially from Germany were holding the stage during the early years of the Republic, but after 1945, German curriculum thought was replaced with USA ideas on curriculum (Aktan, 2013). Watson Dickerman, John J. Rufi, Kate V. Wofford, Lester Beals, Ellsworth Tompkins, Roben J. Maaske visited Turkey in 1950s and effected Turkish education and wrote reports on civic education, primary education, secondary education, teacher education, and village schools' education (Şahin, 1996). In 1950's and 1960's the educators, such as Selahattin Ertürk and Fatma Varış were sent to the USA for their graduate studies, which paved the way for the USA impact on Turkish curriculum and a perspective highlighting curriculum development, curriculum assessment, and teaching methods (Aktan, 2013; Bümen, 2020).

After the 1950s, the curriculum understanding in the form of courses and a list of contents left its place to the curriculum development approach (Demirel, 1992; Gözütok, 2013b). Pilot studies carried out in Bolu and istanbul in 1953-1954, and the pilot school curriculum implemented in Istanbul Atatürk Vocational High School for Girls in 1954-1955 academic year were important steps in the curriculum development studies (Akınoğlu, 2005; Gözütok, 2013). 
The 1968 curriculum, on the other hand, was put into practice in order to be tested and developed as a draft curriculum in 1962 for six years. Although the 1968 curriculum was considered important in terms of reflecting novelties, such as group work, research, examination, and independent learning on the curriculum, it was unsuccessful due to the inadequacy of the practices and the deficiencies in the revision of the curriculum (Gözütok, 2013b). As it was discussed earlier, 1970 was the year of the reconceptualization movement. However, Aktan (2013) stated that the reconceptualization paradigm in the curriculum field in 1970s was not realized in curriculum studies in Turkey focusing on technical and scientific approaches and the idea of curriculum development rather than understanding the curriculum.

In the 1980s, a search for a model began in curriculum development studies in Turkey (Akınoğlu, 2005; Demirel, 1992). Some steps were taken for the standardization and continuity in curriculum development (Gözütok, 2013b). After 1980, instead of collectively developing a curriculum in primary education, subject area-based curricula were developed (Beyaztaş, et al., 2013). In the 1990s, Assessment, Evaluation and Curriculum Development Specialization Commissions were established (Demirel, 1992; Gözütok, 2013b). That period were years when consistency and standardization could not be achieved in curriculum development field (Gözütok, 2013b).

Before analyzing the curriculum theories in 1998 curriculum, it will be useful to mention the background political events in order to see how the curriculum was shaped. It was stated that the political parties represented for the first time between 1968-1998, the 1980 military coup, and the 1982 constitution were important political events (Mızıkacı, 2013). The positive aspects of the 1998 curriculum were that it was made in accordance with the curriculum development model and had a piloting (Şahin, 2013). The curriculum with aims and behavior statements was the product of the behaviorist approach. However, with the behavioral approach in the curriculum, the knowledge/culture transfer necessary for the predetermined desired citizenship was made, and it was detected that the affective domain was covered at a high rate (ERG, 2005). In this respect, although the effects of social efficiency, systematic, and social behaviorist curriculum theories are seen in the curriculum, it can be interpreted that keeping knowledge and culture transfer at the forefront also reflects the liberal curriculum theory.

In 2004, the Ministry of National Education started to work on the innovation of the primary education curriculum (Beyaztaş et al., 2013). It was stated that the goal statements of the 1924, 1926, 1936, 1948, 1962, 1968, 1998 curricula were written with a behavioral approach, whereas the objectives were in the form of achievement expressions with the effect of the constructivist approach in the 2005 curriculum (Akınoğlu, 2005; Beyaztaş et al., 2013). Gözütok (2013b) mentioned that the curricula carried out in the Republican period before 2000 were developed with the influence of the pragmatic philosophy and constructivism movement, but while the existence of those movements could be mentioned theoretically, the practices were not in that direction. Orakçı, et al. (2018) stated that the 2005 curriculum included many components maintaining both personal and social development of the students. In opposition to this view, Beyaztaş et al. (2013) stated that the view that the elements of progressivism and constructivism only existed in 2005 curricula was wrong, and that perspective was already present in the curricula developed since the proclamation of the Republic. In addition, it was stated that there were some problems in the elements that allowed students to construct knowledge actively in terms of achievements, teaching- learning processes, and evaluation. Akinoglu (2005), basically having the same idea with Orakci et. al (2018), stated that the 2005 curriculum had elements that could not get rid of the influence of the behavioral approach. Mızıkacı (2019) stated that constructivism, which entered into the curriculum field by embellishing it with an official and contemporary discourse through 2005 curriculum, actually deepened the current curricular problems and became one of the reasons for today's program erosion. In addition, the fact that for the first time in our country's curriculum development history, the curriculum was prepared without consulting the curriculum development faculty members was criticized (Gözütok, 2013a, 2013b). 
With the 4+4+4 system implemented in the 2012-2013 academic year, compulsory education was increased to 12 years (Gözütok, 2013a; MEB, 2012). There was no existing pilot scheme for the new structure, and it was implemented gradually in the 2012 - 2013 academic year (Gözütok, Ulubey, Akçatepe, Koçer, \& Rüzgâr, 2014). The new system was highly criticized for not having a scientific rationale, lowering the age for participation in primary school to 60 months, leading to participate in an open elementary or high school (Gözütok, 2013a).

In 2017 curriculum, the competencies and skills available in "the European Qualification Framework Reference" were adapted to the conditions of Turkey and the needs of the society. The updates were made regarding the competencies and skills for students in the form of "the Turkish Qualifications Framework", and they were included in the curriculum. Since there was no information on how to associate "Turkish Qualifications Framework" with the curriculum, it was stated that the qualifications were in the form of proforma amendment (Coşkun, 2017).

The history of the USA and Turkey curriculum development has been examined in this study, and it has been seen that the field of curriculum development has been in constant motion and change. Social events, political events, economic crises, competitions among countries, wars and conflicts among countries, national crises are reflected in educational practices and curriculum studies and history. Therefore, these changes in the educational understanding of the country will definitely have an impact on the curricula developed. Since these changes have been directed by the dominant ideology, orientation, and intellectual infrastructure, curriculum theories have had an important place at the focus of curriculum events.

\section{International and National Studies on Curriculum Theories}

When the foreign literature on curriculum theories was examined, it was seen that the studies (Babin, 1978; Cunningham, Johnson \& Carlson, 1992; Schiro, 1992; Lee, Adamson \& Luk, 1995; Ryu, 1998, Cheung, 2000; Cheung \& Wong, 2002, Crummey, 2007; Reding, 2008; Foil, 2008; Jenkins, 2009; Mahlios, Friedman-Nimz, Rice, Peyton, \& O'Brien, 2010; Salleh, Hamdan, Yahya, \& Jantan, 2015; Alsalem, 2018) were done mostly with the teachers, and they mostly aimed to reveal the curriculum theories adopted by the teachers. Among the studies, there were also studies aiming to investigate the curriculum theories of teacher candidates and school administrators, though in a small number. In those studies, "A Curriculum Orientation Profile" developed by Babin (1978) and "Curriculum Orientation Inventory" developed by Cheung (2000) and revised by Cheung \& Wong (2002) were generally used. It was also observed that the studies were generally based on McNeil (1977) and Eisner's (1974) curriculum theory classifications.

It was concluded that the studies in Turkey (Eren, 2010; Geçitli, 2011, Bay, Gündoğdu, Ozan, Dilekçi, \& Özdemir, 2012 Yeşilyurt, 2012; Abakay, Şebin, \& Şahin, 2013; Tanrıverdi \& Apak, 2014; Türe, 2017) were mostly done with teacher candidates. When the studies were examined, it was seen that the studies focusing on curriculum theories in our country have been carried out recently. In those studies, the Curriculum Orientation Inventory, which was developed by Cheung \& Wong (2002) and adapted into Turkish by Eren (2010), was used. Eisner \& Vallance (1974)'s curriculum theory classification was used in almost all of the studies.

\section{Discussion, Conclusion and Implications}

In this review study, the conceptual structure of curriculum theories, different curriculum theories, how these theories reflected on curriculum development processes in Turkey and the USA, and international and national studies on curriculum theories were examined by reviewing the literature. Examples of the definitions of curriculum, curriculum theories, and the variability in those definitions were presented. Discussions about definitions take time and energy, but they also address important 
curricular issues (Ornstein \& Hunkins, 2016). From this point of view, it can be concluded that different definitions and chaotic terminology actually feed the field.

Each view, trend, vision, concept represented by the curriculum definition includes a certain sociopolitical perspective about education, knowledge, social changes, students, and school (Tanner \& Tanner, 1975). This point of view leads us to curriculum theories. Curriculum theories include various classifications in the literature, and within these classifications, there are overlapping theories of different theorists. In some curriculum theories the content of the teaching is seen as more important than the learning process, didactic teaching and learning approaches are used, providing information and intellectual development that will ensure the development of societies is important. In others, the curriculum is regarded as a way to change the society, the skills of solving real-life problems are tried to be gained, and the critical analysis of social problems and inequalities is important. Curriculum theories also ranges widely from the theories that allow students to realize themselves, provide meaningful experiences, and focus on their interests and needs to a theoretical understanding in which the curriculum is planned systematically and clearly defined goals manage the process, and instructional effectiveness and performance tests are prioritized.

Each curriculum represents a choice and stance on how to approach students' education (Posner, 2004). Therefore, many of the curricula and educational reforms developed signify a stance, perspective and choice towards the curriculum and teaching-learning process. In the light of this information, in the present study, it has been tried to shed light on how the curriculum theories directed the process in the USA and Turkey, and the ideological reflections on the curricula were presented with examples.

In this review study, studies on curriculum theory in national and international literature were also examined. It can be interpreted that the awareness of curriculum theories began earlier abroad. Studies abroad generally aimed to reveal the curriculum theories of teachers, and studies in Turkey generally of teacher candidates. The research method and measurement tools used in the studies on curriculum theories were generally the same. For this reason, it is thought that curriculum theories, which are thought to be one of the most important research topics that will feed the intellectual basis of the curriculum area, will provide more fruitful results for the curriculum area by having different study groups, methods and measurement tools in the studies. In addition, as few studies were found dealing with curriculum theories and foreign sources were generally used during this review study, so it is considered important to have studies addressing this issue in Turkey. Curriculum theory studies that support deep questioning and critical thinking in the field of curriculum are also considered important for the future of the field.

As Aktan (2013) stated there has been no macrocurricular approach in curriculum field, which means curriculum studies lack the macrocurricular problems in their research. Instead, technicalscientific-rationalist microcurricular perspectives have been used in the field. Macrocurricular perspective focusing on gender discrimination, ideology, and curriculum history etc. should be the topic of education and the field of curriculum. Taking this into account, with studies questioning the theories of curriculum and thinking infrastructure behind the curricula and curriculum studies, the field can keep itself away from the risk of coming to a deadlock.

\section{References}

Abakay, U., Şebin, K., \& Şahin, M. Y. (2013). Curriculum orientation of pre-service physical education teachers. Life Science Journal, 10(3), 2161-2166.

Akınoğlu, O. (2005). Türkiye'de uygulanan ve değişen eğitim programlarının psikolojik temelleri. Marmara Üniversitesi Atatürk Eğitim Fakültesi Eğitim Bilimleri Dergisi, 22(22), 31-45.

Aktan, S. (2013). Curriculum research in Turkey: From the Ottoman Empire to the Republic. In W. F. Pinar (Ed), International handbook of curriculum research (pp. 514-522). Routledge. 
Alsalem, A. S. (2018). Curriculum orientations and educational philosophies of high school Arabic teachers. International Education Studies, 11(4), 92-95.

Aslan, M. (2000). Cumhuriyet dönemi ilköğretim programları ve belli başlı özellikleri. Milli Eğitim Dergisi. Retrieved on July 25, 2021, from https://dhgm.meb.gov.tr/yayimlar/dergiler/Milli_Egitim_Dergisi/144/arslan.htm

Babin, P. (1978). A curriculum orientation profile. Retrieved July 10, 2021, from https:// eric.ed.gov/?id=ED164613

Bay, E., Gündoğdu, K., Ozan, C., Dilekçi, D., \& Özdemir, D. (2012). Analysis of elementary prospective teachers' curriculum orientations. International Journal of Curriculum and Instructional Studies, 2(3), 15-29.

Beauchamp, G. A. (1972). Basic components of a curriculum theory. Curriculum Theory Network, 3(10), 16-22.

Beauchamp, G. A. (1982). Curriculum theory: Meaning, development, and use. Theory into Practice, 21(1), 23-27.

Bellack, A. A. (1969). 1: History of curriculum thought and practice. Review of Educational Research, 39(3), 283-292.

Bellack, A. A. \& Kliebard, H. M. (1977). Curriculum and evaluation. Berkeley, California.: McCutchan.

Beyaztaş, I. D. , Kaptı, S. B., \& Senemoğlu, N. (2013). An analysis of elementary school curricula since the foundation of Republic of Turkey. Ankara University Journal of Faculty of Educational Sciences (JFES) , 46(2) , 319-344 . DOI: 10.1501/Egifak_0000001308

Bilbao, P. P., Luncido, P. I., Lringan, T. C., \& Javier, R. B. (2008). Curriculum development. Philippines: Lorimar Publishing, INC.

Bintz, W. P. \& Dillard, J. (2007). Teachers as reflective practitioners: Examining teacher stories of curricular change in a 4th grade classroom. Reading Horizons: A Journal of Literacy and Language Arts, 47(3), 203-227.

Bobbitt, J. F. (1918). The curriculum. USA: Houghton Mifflin.

Bümen, N. T. \& Aktan, S. (2014). Yeniden kavramsallaştırma akımı ışığında Türkiye'de eğitim programları ve öğretim alanı üzerine özeleştirel bir çözümleme. Kastamonu Eğitim Dergisi, 22(3), 1123-1144.

Bümen, N. (2020). Türkiye'de eğitim programı uzmanı olmak. Türk Eğitim Bilimleri Dergisi, 18(2), 757776.

Cheung, D. (2000). Measuring teachers' meta-orientations to curriculum: Application of hierarchical confirmatory factor analysis. Journal of Experimental Education, 68(2), 149-165.

Cheung, D. \& Wong, H. (2002). Measuring teacher beliefs about alternative curriculum design. The Curriculum Journal, 13(2), 225-48.

Cunningham, R. (1992). Curriculum orientations of Nebraska home economics teachers. (Unpublished master's thesis). University of Nebraska, Lincoln.

Crummey, M. (2007). Curriculum orientations of alternative education teachers. (Unpublished doctorate dissertation). University of Kansas, Kansas.

Coşkun, Y. D. (2017). Öğretim Programları Arka Plan Raporu. Retrieved 11 May, 2021, from https://www.egitimreformugirisimi.org/wpcontent/uploads/2017/03/Ogretim_Programlari_Arka Plan_Raporu.pdf

Counts, G. S. (1978). Dare the school build a new social order? The John Day Pamphlets, 143(11), 3-56.

Counts, G. S. (2013). Excerpts from dare the school build a new social order? Schools, 10(2), 281-288.

Darling-Hammond, L., Noguera, P., Cobb, V. L., \& Meier, D. (2007). Evaluating "no child left behind". Nation-New York, 284(20), 1-7.

Demirel, Ö. (1992). Türkiye'de program geliştirme uygulamaları. Hacettepe Üniversitesi Eğitim Fakültesi Dergisi, 7(7) 27-43.

Demirel, Ö. (2005). Öğretimde planlama ve değerlendirme öğretme sanatı ( $8^{\text {th }}$ edition). Ankara: Pegem A Yayıncilık. 
Dewey, J. (1902). The child and the curriculum. Chicago. IL: University of Chicago.

Dewey, J. (1986). Experience and education. The Educational Forum, 50(3), 241-252.

Durkheim, E. (1956). Education and sociology. New York: Free Press.

Ellis, A. K. (2004). Exemplars of curriculum theory. New York: Eye on Education.

Ellis, A. K. (2013). Exemplars of curriculum theory. New York: Routledge.

Ellis, A. K. (2015). Eğitim programı modelleri (A. Arı, Translator.). A. Arı, (Ed.) Konya: Eğitim.

Eren, A. (2010). Öğretmen adaylarının program inançlarının görünüm analizi. Kastamonu Eğitim Dergisi, 18(2), 379-388.

Ertürk, S. (2016). Eğitimde program geliştirme. İstanbul: Edge Akademi Yayıncılık.

Foil, J. (2008). Determining the curriculum orientations of public-school administrators using the modified curriculum orientation inventory. (Unpublished doctorate dissertation). University of Kansas, Kansas.

Eisner, E.W. \& Vallance, E. (1974). Conflicting conceptions of curriculum. Berkeley, CA: McCutchan.

ERG. (2005). Yeni öğretim programlarını inceleme ve değerlendirme raporu. Retrieved 27 June, 2021 from https://dergipark.org.tr/en/download/article-file/91065

Geçitli, E. (2011). Ilköğretim Öğretmenlerinin Uygulanan Öğretim Programlarına iliş̧in Yönelimlerinin incelenmesi. (Unpublished master's thesis). Ege Üniversitesi, İzmir.

Goodlad, J. I. (1979). Curriculum inquiry. The study of curriculum practice. Retrieved 12 April, 2021 from https://eric.ed.gov/?id=ED181864

Gözütok, F. D. (2013a). Curriculum development in Turkey. In W. F. Pinar (Ed.), International handbook of curriculum research (pp. 604-618). New York: Routledge.

Gözütok, E. (2013b). Cumhuriyetin ilanından 2013'e Türkiye'de program geliştirme çalışmaları. F. Dilek Gözütok \& Fatma Bıkmaz (Ed.), Cumhuriyet'in ilânından 2013'e öğretim programlarının analizi hayat bilgisi örneği içinde (pp. 1-23). Ankara: Yargı Yayınevi.

Gözütok, D. Ulubey, Ö., Akçatepe, A. G., Koçer, E., \& Rüzgâr, M. E. (2014). Evaluation of adaptation and orientation books prepared in accordance with 4+4+4 regulation. Ankara University Journal of Faculty of Educational Sciences, 47(1), 327-350.

Huebner, D. (1975). The tasks of the curricular theorist. Curriculum theorizing: The reconceptualists, 250-270.

Huenecke, D. (1982). What is curriculum theorizing? What are its implications for practice? Educational Leadership, 39(4), 290-94.

Hursh, D. (2004). No child left behind. In J. O'Donnell, M. Pruyn, \& R. C. Chávez (Ed.), Social justice in these times (pp. 173-190). Connecticut: Information Age Publishing.

Jackson, P. W. (1992). Conceptions of curriculum and curriculum specialists. In P.W. Jackson (Ed), Handbook of Research on Curriculum: A project of the American Educational Research Association (pp. 3-40). New York: Macmillan.

Jenkins, S. B. (2009). Measuring teacher beliefs about curriculum orientations using the modified curriculum orientations inventory. Curriculum Journal, 20(2), 103-120.

Kelly, A. V. (2004). The curriculum: Theory and practice. London: Sage.

Klein, M. F. (1992). A perspective on the gap between curriculum theory and practice. Theory into Practice, 31(3), 191-197.

Kliebard, H. M. (1977). Curriculum theory: give me a "for instance". Curriculum Inquiry, 6 (4), 257-269.

Kliebard, H. M. (1989). Problems of definition in curriculum. Journal of Curriculum and Supervision, 5 (1), 1-5.

Kliebard, H. M. (2004). The struggle for the American curriculum: 1893-1958. New York: Taylor \& Francis.

Kilpatrick, W. (1918). The project method. Teachers College Record, 19(4), 319-335.

Kridel, C. (2010). Encyclopedia of curriculum studies. California: Sage.

Lee, C. K. J., Adamson, R. D., \& Luk, C. M. (1995). Curriculum orientation and perceptions of English language instruction in pre-service teachers. International Teacher Education Conference (ITEC'95): 
Teacher Education in the Asian Region (pp. 191-197). Hong Kong: The University of Hong Kong. Retrieved 15 August, 2021 from https://rep ository.eduhk.hk/en/publications/curriculumorientation-and-perceptions-of-english-lang uage-instru-4

Macdonald, J. B. (1971). Curriculum theory. The Journal of Educational Research, 64(5), 196-200.

Mahlios, M., Friedman-Nimz, R., Rice, S., Peyton, V., \& O'Brien, B. (2010). Measuring teachers' curricular beliefs: From Hong Kong to the United States. Curriculum and Teaching, 25 (2), 81-100.

Marzooghi, R. (2016). Curriculum typology. International Journal of English Linguistics, 4(8), 21-28.

McCutcheon, G. (1982). What in the world is curriculum theory? Theory into Practice, 21(1), 18-22.

McNeil, J.D. (1977). Curriculum: A comprehensive introduction. Boston: Little, Brown.

MEB (1948). Türkiye Cumhuriyeti Kültür Bakanlığı ilkokul programı. İstanbul: Devlet Basımevi.

MEB (2012). 12 yıl zorunlu eğitim sorular - Cevaplar. Ankara.

Mızıkacı, F. (2013). 1998 ilköğretim programı. F. Dilek Gözütok ve Fatma Bıkmaz (Ed.), Cumhuriyet'in ilânından 2013'e öğretim programlarının analizi hayat bilgisi örneği içinde (pp. 167-175). Ankara: Yargı Yayınevi.

Mızıkacı, F. (2017). Müfredat. Eleştirel Pedagoji Dergisi, 51-52.

Mızıkacı, F. (2019). Eğitim programlarının karmaşık kodları: İdeoloji, bilgi, pedagoji söylemi ve değerlendirme. F. H. Bıkmaz ve B. Aslan (Ed.), Prof. Dr. Mehmet Ali Kısakürek'e Armağan içinde (pp. 219-229). Ankara: Ankara Üniversitesi Basımevi.

Morris, R. C. \& Hamm, R. (1976). Toward a curriculum theory. Educational Leadership, 33(4), 299-300.

Nestel, D. \& Bearman, M. (2015). Theory and simulation-based education: Definitions, worldviews and applications. Clinical Simulation in Nursing, 11(8), 349-354.

Null, W. (2016). Curriculum: From theory to practice. Plymouth: Rowman \& Littlefield.

Oliva, P. (1977). The curriculum. Theoretical dimensions. New York: London.

Oliva, P. F. (1988). Developing the curriculum. Glenview, Illinois: Scott, Foresman/Little, Brown College Division.

Orakçı, Ş., Durnalı, M., \& Özkan, O. (2018). Curriculum reforms in Turkey. In O. Karnaukhova, A. Udovikina, \& B. Christiansen (Ed.), Economic and geopolitical perspectives of the commonwealth of independent states and Eurasia (pp. 225-251). Pennsylvania, United States: IGI Global. doi: 10.4018/978-1-5225-3264-4.ch010

Ornstein, A. C. \& Hunkins, F. P. (1998). Curriculum: Foundation, principles, and issues. Boston: Pearson Education Inc.

Ornstein, A. C. \& Hunkins, F. P. (2016). Curriculum: Foundations, principles, and issues ( $7^{\text {th }}$ Edition). England: Pearson.

Oxford (2021). Oxford Advanced Learners Dictionary. Retrieved 23 August, 2021, from https://www.oxfordlearnersdictionaries.com/definition/english/theory?q=theory

Phenix, P. (1962). The disciplines as curriculum content. In A. H. Passow (Ed), Curriculum crossroads (pp. 227-245). New York, NY: Teachers College Press.

Pinar, W., Reynolds, W. M., Slattery, P., \& Taubman, P. M. (2004). Understanding curriculum: An introduction to the study of historical and contemporary curriculum discourses. Bern, Switzerland: Peter Lang Publishing.

Portelli, J. P. (1987). On defining curriculum. Journal of Curriculum and Supervision, 2(4), 354-67.

Porter, A. C. (1990). Assessing National Goals: Some Measurement Dilemmas. In: "The Assessment of National Educational Goals: Proceedings of the 1990 ETS Invitational Conference (pp. 21-42), New York. Retrieved 05 May, 2021, from https://files.eric.ed.gov/fulltext/ED341714.pdf

Posner, G. J. (1995). Analyzing the curriculum. New York: McGraw-Hill Humanities Social.

Rasco, J. F. A. (2016). In search of the lost curriculum. Counterpoints, 491, 137-155.

Reding, C. (2008). Curricular orientations of catholic school teachers and administrators. (Unpublished doctorate dissertation). University of Kansas, Kansas.

Ryu, S. H. (1998). Curriculum orientations and professional teaching practices reported by Korean secondary school home economics teachers and teacher educators. Unpublished doctorate 
dissertation. The Ohio State University, Ohio, USA. Retrieved 28 August, 2021 from https://etd.ohiolink.edu/apexprod/rws_etd/send_file/send?accession=osu1487951907960049\&d isposition=inline

Salleh, H., Hamdan, A. R., Yahya, F., \& Jantan, H. (2015). Curriculum orientation of lecturers in teacher training college in Malaysia. Journal of Education and Practice, 6(2), 70-76.

Saylor, J. G., \& Alexander, W. M. (1974). Planning curriculum for schools. New York: Holt, Rinehart and Winston

Schiro, M. S. (1992). Educators' perceptions of the changes in their curriculum belief systems over time. Journal of Curriculum and Supervision, 7, 250-86.

Schiro, M. S. (2012). Curriculum theory: conflicting visions and enduring concerns. USA: Sage Publications.

Schiro, M. S. (2020). Eğitim programı kuramları: Çatışmalı görüşler ve süregelen sorunlar (F. Mızıkacı, Translator). Ankara: Pegem Akademi Yayınları.

Schubert, W. H. (1986). Curriculum: Perspective, paradigm, and possibility. Prentice Hall.

Schubert, W. H. (1996). Perspectives on four curriculum traditions. Educational Horizons, 74(4), 16976.

Schwab, J. J. (1969). The practical: A language for curriculum. The School Review, 78(1), 1-23

Spencer, H. (1884). What knowledge is of most worth. New York: John B, Alden.

Sönmez, V. (2015). Program geliştirmede ögretmen el kitabı (18 ${ }^{\text {th }}$ edition). Ankara: Anı Yayıncılık.

Squires, A. (1990). First degree: the undergraduate curriculum. ERIC documented 326168.

Şahin, M. (1996). Türkiye'de öğretmen yetiştirme uygulamalarında yabancı uzmanların yeri. (Unpublished doctorate dissertation). Dokuz Eylül Üniversitesi, İzmir, Türkiye.

Şahin, S. A. (2013). 1998 ilköğretim programı (hayat bilgisi dersi). F. Dilek Gözütok ve Fatma Bıkmaz (Ed.), Cumhuriyet'in ilânından 2013'e öğretim programlarının analizi hayat bilgisi örneği içinde (pp. 177-207). Ankara: Yargı Yayınevi.

Taba, H. (1932). The dynamics of education. New York: Harcourt, Brace and Co.

Tanner, D., \& Tanner, L. N. (1975). Curriculum development: Theory into practice. New York, NY: Macmillan.

Tanrıverdi, B., \& Apak, Ö. (2014). Pre-service teachers' beliefs about curriculum orientations. ProcediaSocial and Behavioral Sciences, 116 (2014), 842-848. doi: 10.1016/j.sbspro.2014.01.308

Türe, E. (2017). Öğretmenlerin eğitim programı teorilerine ilişkin yönelimleri ve öğrenme-öğretme sürecine yansımaları. (Unpublished doctorate dissertation). Ankara Üniversitesi, Ankara, Türkiye.

Türe, E. (2013). 1936 ilkokul programı (hayat bilgisi dersi). F. Dilek Gözütok ve Fatma Bıkmaz (Ed.). Cumhuriyet'in ilânından 2013'e öğretim programlarının analizi hayat bilgisi örneği içinde (pp. 80100). Ankara: Yargı Yayınevi.

Türk Dil Kurumu. (2021). Türk Dil Kurumu güncel Türkçe sözlük. Retrieved 02 August, 2021, from www.tdk.gov.tr

Tyler. R. W. (1975). Specific approaches to curriculum development. In J. Schaffarzick and D. Hampson (Ed.), Strategies for curriculum development. Berkeley, CA: McCutchan.

Tyler, R. W. (1977). Toward improved curriculum theory: The inside story. Curriculum Inquiry, 6(4), 251-256.

Tyler, R. W. (2014). Eğitim programlarının ve öğretimin temel ilkeleri. M. Emir Rüzgar, Berna Aslan. (Çev.) Ankara: Pegem Akademi Yayıncılık.

Varış, F. (1996). Eğitimde program geliştirme teori ve teknikler: Ankara: Ankara Üniversitesi Basımevi.

Walker, D. F. (1982). Curriculum theory is many things to many people. Theory into practice, 21(1), 6265.

Walker, D. F., \& Soltis, J. F. (2004). Curriculum and aims. New York: Teachers College Press.

Yeşilyurt, E. (2012). Bir eğitim programının nasıl olması gerektiğine ilişkin öğretmen adayı inançları. Ejournal of New World Sciences Academy, 8(1), 133- 145. 
Yılmaz, G. (2021). Öğretmenlerin program okuryazarlık düzeyleri, program yönelimleri ve programa bağlılık düzeyleri arasındaki ilişkinin incelenmesi. (Unpublished master's thesis). Gaziantep Üniversitesi Eğitim Bilimleri Enstitüsü, Gaziantep, Türkiye. 


\section{Uluslararası Eğitim Programları ve Öğretim Çalışmaları Dergisi \\ 11(2), 2021, 237-260 \\ www.ijocis.com}

EPÖDER

\section{TÜRKÇE GENIŞ ÖZET}

\section{Eğitim Programı Kuramı: Bir Derleme Çalışması}

\section{Giriş}

Eğitim programı, bir eğitim sistemine yön veren ve toplumda yetiştirilmek istenen bireyleri tanımlayan eğitimin anayasasıdır. Program geliştirmeye ilişkin alınan kararlar tüm öğretim sürecini etkileyecek önemli ipuçları verir. Programlar hazırlanırken "hangi bilgi en değerlidir, ne öğretmeliyiz (Spencer, 1884); neden bir şeyi öğretmeyi diğerine tercih etmeliyiz, hangi bilgiye kim ulaşabilir, programın farklı parçalarından bir bütün elde etmek için bu parçalar arası nasıl ilişki kurulmalıdır" (Kliebard, 1977) gibi sorular program geliştirme süreçleri açısından yanıtlanması gereken önemli sorulardır. Ayrıca ne öğretilmeli ve kime öğretilmeli, hangi koşullarda öğretilmeli, hangi amaç bağlamında öğretilmeli, program kararları alırken hangi süreçler kullanılmalı (Null, 2016); programlarda yer alan bilginin doğası kaynağını didaktik öğretilerden mi, bireysel anlamlandırmalardan mı, yetenek ve yeterliklerden mi yoksa kültürel ve ahlaki bakış açılarından mı almaktadır gibi derin sorgulamalara intiyaç vardır. Bu sorulara bulunan yanıtlar ise bizi eğitim programı kuramlarına götürmektedir (Null, 2016).

$\mathrm{Bu}$ çalışmada eğitim program kavramını tanımlamadan önce eğitim programı ve kuram sözcüklerinin kavramsal yapıları üzerinde durulmuştur. Eğitim programı kavramı tanımlanırken tanımlardan bazıları öğrencinin deneyimlerini, bazıları yetişkin hayatına hazırlık için gerekli olan yeterlikleri ön plana alırken bazı tanımlar programın tüm ögelerini göz önünde bulundurarak programı bir sistem olarak tanımlamakta, bazıları ise programı yalnızca içerik olarak ele almaktadırlar (Bilbao ve diğ., 2008; Bobbit, 1918; Demirel, 2006; Dewey, 1902; Ertürk 2016; Kliebard, 1989; Oliva, 1988; Ornstein \& Hunkins, 2016; Phenix, 1962; Squires, 1990; Saylor \& Alexander, 1974; Taba, 1932; Tyler, 1975; Varış, 1996). Bu tanımlar incelediğinde eğitim programına ilişkin alanyazında çok fazla tanım olduğu görülmekte (Bellack \& Kliebard, 1977; Kliebard, 1989, Oliva, 1977; Portelli, 1987, Rasco, 2016, Schubert, 1986) ve bu durum da eğitim programı kavramının kaotik yapısına işaret etmektedir.

Eğitim programı kuramı kavramını tartışmadan önce kuram kavramı da incelenmiş ve çok farklı tanımlamalar olduğu sonucuna ulaşılımıştır (Beauchamp, 1982; TDK, 2021; OXFORD, 2021). Beauchamp (1972)'ın da belirttiği gibi kuram kavramına ilişkin farklı tanımlar mevcuttur ancak kuram kavramı, kuramın geliştirildiği alana özgü olarak kendine has bir anlam kazanmaktadır. Eğitim programı kuramı kavramındaki kuram sözcüğü de tam olarak böyle bir süreçten geçmiştir.

Eğitim programı kuramından ilk kez Chicago Üniversitesinde 1947 yılında düzenlenen konferansta ve ardından yazılan "Toward Improved Curriculum Theory" makalesinde bahsedilmiştir (Klein, 1992; Kliebard, 1977; Tyler, 1977). Beauchamp (1982), eğitim programı kuramını bir okulun programına anlam katan ilişkisel bir bütün içinde hareket eden önermeler bütünü olarak tanımlarken McCutcheon (1982) da aynı bakış açısıyla eğitim programı kuramını program olgusunun bir dizi analizi, yorumlanması ve anlayışı olarak ele almıştır.

Alanyazın incelendiğinde, Eğitim Programı Kuramı (Curriculum Theory) kavramının program inançları (curriculum beliefs), eğitimsel değer yönelimleri (educational value orientations), program 
ideolojileri (curriculum ideologies), program yönelimleri (curriculum orientations) gibi kavramlarla aynı şeyi ifade eden farklı kavramlarla ele alındığı görülmüştür (Cheung \& Wong, 2002; Schiro, 2012; Yılmaz, 2021).

Eğitim programı kuramları farklı program kuramcıları tarafından farklı şekillerde sınıflandııımış ve isimlendirilmiştir. Bu çalışmada Eisner \& Vallance (1974), Mcneil (1977), Posner (1995), Schubert (1996), Ornstein \& Hunkins (1998), Kliebard (2004), Ellis (2004), Schiro (2012) ve Null (2016)'un eğitim program kuramları sınıflandırmasına yer verilmiş ve açıklamalar yapılmıştır. Araştırmada, eğitim programı kuramlarının eğitime ve eğitim programı çalışmalarına nasıl yansıdığını betimlemek için yurt dışı ve yurt içindeki program tarihçesine kronolojik sırayla yer verilmiş ve program tarihi için önemli olaylar farklı eğitim programı kuramları ile ilişkilendirilmiştir.

Eğitim programı kuramının yurt içi (Eren, 2010; Geçitli, 2011, Bay, Gündoğdu, Ozan, Dilekçi, \& Özdemir, 2012 Yeşilyurt, 2012; Abakay, Şebin, \& Şahin, 2013; Tanrıverdi \& Apak, 2014; Türe, 2017) ve yurt dışı (Babin, 1978; Cunningham, Johnson \& Carlson, 1992; Schiro, 1992; Lee, Adamson \& Luk, 1995; Ryu, 1998, Cheung, 2000; Cheung \& Wong, 2002, Crummey, 2007; Reding, 2008; Foil, 2008; Jenkins, 2009; Mahlios, Friedman-Nimz, Rice, Peyton, \& O'Brien, 2010; Salleh, Hamdan, Yahya, \& Jantan, 2015; Alsalem, 2018) araştırmalarda nasıl ele alındığını betimlemek için bu konuyu ele alan araştırmalar ve tezler incelenmiş ve yapılan araştırmalara ilişkin bazı çıkarımlarda bulunulmuştur.

Yukarıdaki bilgiler doğrultusunda, eğitim programı kuramlarının kaotik olan kavramsal yapısını sorgulamak, eğitim programı kuramlarını detaylı incelemek, eğitim program çalışmaları ile kuramlarını ilişkilendirmek ve araştırmalara nasıl yansıdığını ortaya koymak amacıyla gerçekleştirilen bu araştırmada, eğitim programı kuramları konusunda yapılmış olan çalışmalar incelenmiştir. Bu amacı gerçekleştirmek için "eğitim programı kuramı nedir, eğitim programı kuramları nasıl sınıflandırımaktadır, eğitim programı kuramları ile program tarihi nasıl ilişkilendirilebilir ve eğitim programı kuramlarına ilişkin nasıl araştırmalar yapılmaktadır?" sorularına yanıt aranmıştır.

\section{Yöntem}

Eğitim programı kuramı kavramının çalışıldığı araştırmaların incelenmesi yoluyla oluşturulmuş bu çalışma bir alanyazın derleme çalışmasıdır. Alanyazında yapılan incelemeler sonucunda, yurt içinde ve yurt dışında yapılan çalışmalar dikkate alınmıştır. Çalışmalar incelenirken araştırmaların başlığı, çalışmaların yapıldığı yıl ve ülke, araştırmaların çalışma grubu, amacı, araştırmalarda kullanılan veri toplama araçları, veri analizi süreçleri, araştırmaların bulguları, sonuçları ve önerilerini içeren bir analiz yapılmıştır. Çalışma kapsamında olacak araştırmalar ScienceDirect, Jstor, Google Scholar, Proquest ve Ulusal Tez Merkezi veri tabanlarında 'Eğitim Programı Kuramı', 'Eğitim Programı İdeolojisi' ve 'Eğitim Programı Yönelimleri' kelimeleri kullanılarak taranmıştır

Ayrıca yurt dışında 1900 'lerin başından itibaren program alanını gerek alanda çalışan Amerikalı eğitim programcıları gerekse yapılan çalışmalar açısından yoğun bir şekilde etkilemiş olması gerekçesi ile Amerika' da ve Türkiye'de eğitim programı kuramlarının bu iki ülkedeki eğitim sistemlerini ne şekilde etkilediği bu alanda yapılan literatür çalışması ile ortaya konulmaya çalışımıştır.

\section{Tartışma, Sonuç ve Öneriler}

Bu derleme çalışmasında eğitim programı kuramlarının kavramsal yapısı, farklı program kuramları, bu kuramların program çalışmalarına etkisi ve program kuramları ile ilgili yurt içi ve yurtdışında yapılan çalışmalar alanyazın taraması yapılarak incelenmiştir.

Eğitim programı kuramının kavramsal yapısı ele alınmış ve alanyazın incelemeleriyle bu kavrama ilişkin kaotik bir yapının bulunduğu saptanmıştır. Eğitim programı kuramı, program yönelimleri, program ideolojileri gibi farklı şekillerde ele alınan eğitim programı kuramları ve bu kuramlara ait 
sınıflandırmalar incelendiğinde farklı adlandırmalar olsa da kuramların ilkelerinin aynı şeyleri ifade ettiği sonucuna varılmıştır. Program kuramları arasındaki bu benzerliği ortaya koymak için farklı kuramcıların farklı sınıflandırmaları geniş bir tablo içerisinde sunulmuştur. Eğitim programları alanına yön veren önemli olayların kronolojik sıra ile incelemesi yapılmış ve alan için dönüm noktaları sayılabilecek bu olaylarda farklı eğitim programı kuramlarının yansımaları görülmüştür.

Eğitim programı kuramlarının çalışıldığı yurt dışı ve yurt içi araştırmalar incelendiğinde ise yurt dışı literatürüne göre program kuramlarına yönelik farkındalığın çok daha geç kazanıldığı yorumu yapılabilir. Yurt dışı çalışmaları genel olarak öğretmenlerin program kuramlarını betimlemek için yapılmış, yurt içi çalışmalar ise yoğunlukla öğretmen adaylarının program kuramlarının araştırılması üzerine yoğunlaşmıştır.

$\mathrm{Bu}$ çalışmada eğitim programı kuramlarının ele alındığı ulusal yayınların çok sınırlı olduğu görülmüştür. Eğitim programı kuramlarını ele alan daha çok çalışmanın ülkemiz alanyazınına kazandırılması önemli görülmektedir. Eğitim Programları ve Öğretim alanının düşünsel temellerini ve art alanını besleyeceği düşünülen eğitim programı kuramını inceleyen çalışmalar hem araştırmacılara bu konuda veri sağlayabilir hem de alanyazındaki boşluğun doldurulmasına yardımcı olabilir. 
